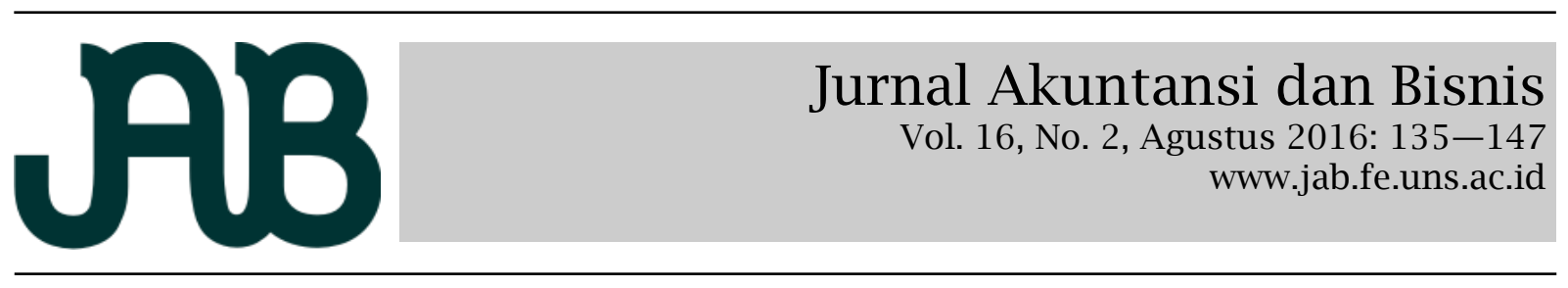

\title{
KERUGIAN DAERAH, KESEJAHTERAAN MASYARAKAT DAN OPINI PEMERIKSAAN ATAS LAPORAN KEUANGAN PEMERINTAH DAERAH DI INDONESIA
}

\section{SIGIT ISTIYANTO}

Badan Pemeriksa Keuangan (BPK) Perwakilan Jawa Tengah

\begin{abstract}
A B S T R A C T
This study aims to obtain empirical evidence about the effect of regions loss (the number and value of the findings of regions loss) and social welfare (HDI, the GDP per capita, and the level of income disparity) to the financial statements opinion of the local government. This study uses purposive sampling. The sample used in this study is as much as 158 local government audited by BPK in 2013 and 2014. This study uses multiple linear regression analysis to test the classical assumption that includes data normality, heteroscedasticity, and multicollinearity test using the program Statistical Package for the Social Science (SPSS). The test results showed that the loss of area significantly influence the financial statements opinion of the local government, while the number of findings loss of area, HDI, the GDP per capita, and the level of income disparity does not affect the financial statements opinion of the local government.x

Keywords: regions loss, social walfare, the financial statements opinion of the local government

Penelitian ini bertujuan untuk memperoleh bukti empiris tentang pengaruh kerugian daerah (jumlah dan nilai temuan kerugian daerah) dan kesejahteraan masyarakat (IPM, PDRB per Kapita, dan Tingkat Kesenjangan Pendapatan) terhadap opini pemeriksaan atas LKPD. Penelitian ini mengunakan teknik pengambilan sampel purposive sampling. Sampel yang digunakan dalam penelitian ini adalah 158 pemerintah daerah yang diaudit oleh Badan Pemeriksa Keuangan untuk tahun anggaran 2013 dan 2014. Penelitian ini menggunakan analisis regresi linier berganda. Hasil pengujian menunjukkan bahwa nilai kerugian daerah berpengaruh signifikan terhadap opini pemeriksaan atas LKPD, sedangkan jumlah temuan kerugian daerah, IPM, PDRB per kapita, dan Tingkat Kesenjangan Pendapatan tidak berpengaruh terhadap opini pemeriksaan atas LKPD.

Kata Kunci: kerugian daerah, kesejahteraan masyarakat, opini pemeriksaan atas LKPD
\end{abstract}

\section{PENDAHULUAN}

Reformasi bidang keuangan negara ditandai dengan terbitnya paket tiga Undang-Undang (UU) bidang keuangan negara, yaitu UU Nomor 17 Tahun 2003 tentang Keuangan Negara, UU Nomor 1 Tahun 2004 tentang Perbendaharaan Negara dan UU Nomor 15 Tahun 2004 tentang Pemeriksaan Pengelolaan dan Tanggung Jawab Keuangan Negara. Dalam rangka memperkokoh keberadaan dan kedudukan Badan Pemeriksa Keuangan (BPK) sebagai satu lembaga negara yang bebas dan mandiri, pemerintah menerbitkan UU Nomor 15 Tahun 2006 tentang Badan Pemeriksa Keuangan. Salah satu jenis pemeriksaan yang menjadi tugas dan wewenang BPK berdasarkan amanat Undang-Undang Dasar 1945 Pasal 23E, UU Nomor 15 Tahun 2004, dan UU Nomor 15 Tahun 2006 adalah pemeriksaan keuangan.

Pemeriksaan keuangan dilaksanakan dalam rangka memberikan pernyataan opini mengenai tingkat kewajaran informasi yang disajikan dalam laporan keuangan. UU Nomor 15 Tahun 2004 menyebutkan bahwa terdapat empat jenis pernyataan opini yang dapat diberikan BPK 
terhadap laporan keuangan pemerintah, yaitu opini wajar tanpa pengecualian (WTP), opini wajar dengan pengecualian (WDP), opini tidak wajar (TW), dan opini tidak menyatakan pendapat (TMP) atau pernyataan menolak memberikan opini. Pemberian opini merupakan bentuk apresiasi dari BPK atas hasil pemeriksaan laporan keuangan, disamping pemberian rekomendasi lainnya.

BPK memberikan opini atas Laporan Keuangan Pemerintah Daerah (LKPD) berdasarkan hasil pemeriksaan yang memuat temuan, kesimpulan, dan rekomendasi. Setiap temuan dapat terdiri atas satu atau lebih permasalahan, yaitu berupa kelemahan sistem pengendalian intern (SPI) dan/ atau ketidakpatuhan terhadap ketentuan peraturan perundangundangan. Ketidakpatuhan ini dapat mengakibatkan kerugian negara/daerah, potensi kerugian negara/daerah, kekurangan penerimaan, penyimpangan administrasi, ketidakhematan, ketidakefsienan, atau ketidakefektifan (Badan Pemeriksa Keuangan 2015). LKPD yang diaudit oleh BPK merupakan bentuk pertanggungjawaban pemerintahan sehingga keandalan dan kualitas auditnya harus bisa dipercaya untuk mencegah terjadinya penyalahgunaan wewenang.

Berdasarkan data Ikhtisar Hasil Pemeriksaan Semester (IHPS) I Tahun 2015 yang diterbitkan BPK, diketahui bahwa pada tahun 2015 BPK telah menyelesaikan pemeriksaan atas 504 LKPD Tahun Anggaran (TA) 2014. Hasil pemeriksaan atas LKPD, BPK memberikan 251 opini WTP (49,80\%), 230 opini WDP $(45,64 \%), 4$ opini TW (0,79\%), dan 19 opini TMP (3,77\%). Dibandingkan tahun 2013, LKPD yang mendapatkan opini WTP meningkat sebesar 20,03\% atau dari 29,77\% pada tahun 2013 menjadi 49,80\% pada tahun 2014.

Kerugian daerah merupakan salah satu bentuk ketidakpatuhan terhadap ketentuan peraturan perundang-undangan. Secara umum, permasalahan yang mengakibatkan kerugian daerah banyak ditemukan dalam pengelolaan Belanja Modal dan Belanja Barang dan Jasa. Permasalahan umumnya terjadi karena pejabat yang bertanggung jawab lalai dan tidak cermat dalam menaati dan memahami ketentuan yang berlaku, belum optimal melaksanakan tugas dan tanggung jawab, lemah dalam melakukan pengawasan dan pengendalian, serta sengaja tidak mempertanggungjawabkan pengelolaan dana (BPK 2015).

Hasil pemeriksaan LKPD juga mengungkapkan 5.993 permasalahan ketidakpatuhan terhadap ketentuan peraturan perundang-undangan senilai Rp3,20 triliun. Dari permasalahan ketidakpatuhan tersebut, sebanyak 3.638 permasalahan berdampak fnansial yang meliputi 2.422 (40,41\%) kerugian daerah senilai Rp1,42 triliun, 324 (5,41\%) potensi kerugian daerah senilai Rp1,41 triliun, dan 892 (14,88\%) kekurangan penerimaan senilai Rp373,70 miliar. Selain itu, terdapat 2.355 (39,30\%) kelemahan administrasi. Data tersebut menunjukkan bahwa kerugian daerah menjadi permasalahan berdampak finansial terbesar (40,41\%) dalam pemeriksaan atas LKPD.

Keberadaan dan fungsi BPK sebagai lembaga pemeriksa pengelolaan dan pertanggungjawaban keuangan negara juga diharapkan mampu mewujudkan tata kelola keuangan negara yang akuntabel, transparan, dan digunakan sebesarbesarnya untuk kemakmuran dan kesejahteraan rakyat. Selain memberikan opini atas laporan keuangan, BPK juga memberikan penilaian atas upaya instansi pemerintah dalam meningkatkan kemakmuran rakyat. Dengan cara demikian, BPK dapat mempertegas manfaat hasil pemeriksaan BPK dengan upaya peningkatan kesejahteraan masyarakat.

Masyarakat sebagai salah satu pengguna hasil pemeriksaan diharapkan melakukan pengawasan terhadap kinerja pengelolaan keuangan di pemerintahan daerahnya. Perbaikan yang dilakukan dilakukan harus secara berkesinambungan dan sekaligus dapat memperkuat upaya bersama untuk meningkatkan kesejahteraan masyarakat. Pendapatan masyarakat manjadi salah satu faktor tingkat kesejahteraan masyarakat. Pendapatan tersebut dapat dilihat dari produk domestik regional bruto (PDRB) per 
kapita dan sekaligus dapat digunakan untuk mengukur tingkat kesenjangan pendapatan masayarakat. Selain itu, tingkat pembangunan masyarakat menunjukkan tingkat kemajuan yang dicapai suatu masyarakat. Tingkat pembangunan masyarakat dapat diukur salah satunya melalui Indeks Pembangunan Manusia (IPM). Tata kelola pemerintahan yang baik mensyaratkan adanya keberadaan masyarakat yang tingkat pembangunannya baik pula (Ramachandran 2002).

Tingkat pendapatan masyarakat, tingkat kesenjangan pendapatan, dan pembangunan manusia dapat menggambarkan tingkat kesejahteraan masyarakat dan diharapkan tergambar dalam kualitas laporan keuangan suatu pemerintah daerah. Adzani dan Martani (2014) menyatakan bahwa peranan masyarakat madani memiliki pengaruh positif yang signifikan terhadap opini audit maupun peningkatan opini audit. Variabel yang berpengaruh tersebut adalah tingkat pembangunan manusia, tingkat pendidikan, dan tingkat pendapatan.

Berdasarkan data Badan Pusat Statistik (BPS) dan IHPS I Tahun 2015 dapat diperoleh informasi mengenai tingkat kesejahteraan masayarakat dan opini yang diperoleh pemerintah daerah. Beberapa contoh pemerintah daerah yaitu Pertama, Kota Yogyakarta (Provinsi Daerah Istimewa Yogyakarta) dengan capaian IPM tertinggi sebesar 83,78 (kategori "sangat tinggi") dan PDRB per kapita sebesar Rp60.567.000,00 serta memperoleh opini WTP dengan jumlah temuan sebanyak tiga temuan sebesar Rp77.480.000,00. Kedua, Kabupaten Batu Bara (Provinsi Sumatera Utara) dengan capaian IPM sebesar 65,50 (kategori "sedang") dan PDRB per kapita sebesar Rp59.540.000,00 memperoleh opini TMP dengan jumlah temuan sebanyak tiga temuan sebesar Rp1.090.390.000,00. Ketiga, Kabupaten Asmat (Provinsi Papua) dengan capaian IPM sebesar 45,91 (kategori "rendah") dan PDRB per kapita sebesar Rp17.170.000,00 memperoleh opini WTP dengan jumlah temuan sebanyak enam temuan sebesar Rp2.513.400.000,00. Keempat, Kabupaten Mappi (Provinsi Papua) dengan capaian IPM sebesar 55,74 (kategori "rendah") dan PDRB per kapita sebesar Rp18.636.000,00 memperoleh opini TMP dengan jumlah temuan sebanyak lima temuan sebesar Rp125.243.610.000,00.

Kota Yogyakarta dan Kabupaten Mappi menunjukkan bahwa opini yang diterima (WTP dan TMP) sejalan dengan besaran kerugian daerah dan tingkat kesejahteraan masyarakat yang dicapai. Akan tetapi, Kabupaten Batu Bara dan Kabupaten Asmat menunjukkan hal yang sebaliknya bahwa opini yang diterima (TMP dan WTP) tidak sejalan dengan besaran kerugian daerah dan tingkat kesejahteraan masyarakat yang dicapai. Berdasarkan data tersebut peneliti tertarik untuk melakukan penelitian dan membahas mengenai apakah kesejahteraan rakyat berpengaruh terhadap pemberian opini pada pemeriksaan atas LKPD dan apakah kerugian daerah yang merupakan permasalahan berdampak finansial tertinggi juga berpengaruh terhadap opini pada pemeriksaan atas LKPD.

Sesuai dengan latar belakang masalah yang telah diuraikan sebelumnya, maka penelitian yang akan diuji adalah Apakah faktor jumlah temuan kerugian daerah berpengaruh terhadap opini pemeriksaan atas LKPD?, Apakah faktor nilai temuan kerugian daerah berpengaruh terhadap opini pemeriksaan atas LKPD?, Apakah faktor tingkat IPM berpengaruh terhadap opini pemeriksaan atas LKPD?, Apakah faktor PDRB per kapita berpengaruh terhadap opini pemeriksaan atas LKPD?, Apakah faktor tingkat kesenjangan pendapatan berpengaruh terhadap opini pemeriksaan atas LKPD?

Berdasarkan pertanyaan penelitian di atas, maka tujuan dari penelitian ini adalah untuk mendapatkan bukti empiris dan menganalisis pengaruh jumlah temuan kerugian daerah, nilai temuan kerugian daerah, tingkat IPM, tingkat PDRB per kapita, dan tingkat kesenjangan pendapatan terhadap opini pemeriksaan atas LKPD.

\section{T I N JA UAN PUS T A K A D A N PENGEMBANGAN HIPOTESIS \\ Opini Pemeriksaan}


UU Nomor 15 Tahun 2004 menyebutkan bahwa opini adalah "pernyataan profesional sebagai kesimpulan pemeriksa mengenai tingkat kewajaran informasi yang disajikan dalam laporan keuangan." Selanjutnya dalam penjelasan pasal 16 ayat (1) undang-undang tersebut disebutkan bahwa opini merupakan pernyataan profesional pemeriksa mengenai kewajaran informasi keuangan yang disajikan dalam laporan keuangan yang didasarkan pada kriteria: (i) kesesuaian dengan standar akuntansi pemerintahan, (ii) kecukupan pengungkapan (adequate disclosure), (iii) kepatuhan perundang-undangan, dan (iv) efektivitas sistem pengendalian intern.

Opini yang dapat diberikan BPK terhadap laporan keuangan pemerintah adalah salah satu dari keempat jenis opini berikut ini: wajar tanpa pengecualian, wajar dengan pengecualian, tidak wajar, atau tidak menyatakan pendapat.

\section{Wajar tanpa pengecualian unqualified opinion)}

Opini wajar tanpa pengecualian menyatakan bahwa laporan keuangan telah disajikan dan diungkapkan secara wajar dalam semua hal yang material sesuai dengan Standar Akuntansi Pemerintahan (SAP). Opini wajar tanpa pengecualian mengindikasikan bahwa informasi keuangan dalam laporan keuangan dapat digunakan oleh para pengguna laporan keuangan sebagai dasar dalam pengambilan keputusan.

\section{Wajar dengan pengecualian (WDP/ qualified opinion)}

Opini wajar dengan pengecualian menyatakan bahwa laporan keuangan telah disajikan dan diungkapkan secara wajar dalam semua hal yang material sesuai SAP, kecuali untuk dampak hal-hal yang berhubungan dengan yang dikecualikan. Hal-hal yang dikecualikan kewajaran penyajian dan pengungkapannya dinyatakan dalam laporan hasil pemeriksaan yang memuat opini tersebut.

Opini wajar dengan pengecualian mengindikasikan bahwa informasi keuangan dalam laporan keuangan yang tidak dikecualikan kewajaran penyajian dan pengungkapannya dalam opini pemeriksa dapat digunakan oleh para pengguna laporan keuangan sebagai dasar dalam pengambilan keputusan. Sedangkan informasi keuangan atas hal-hal yang dikecualikan tidak memiliki kehandalan untuk digunakan sebagai dasar dalam pengambilan keputusan.

\section{Tidak wajar (TW/ adverse opinion)}

Opini tidak wajar menyatakan bahwa laporan keuangan tidak disajikan dan diungkapkan secara wajar dalam semua hal yang material sesuai dengan SAP. Opini tidak wajar mengindikasikan bahwa informasi keuangan dalam laporan keuangan tidak memiliki kehandalan untuk digunakan sebagai dasar dalam pengambilan keputusan.

\section{Menolak memberikan pendapat atau tidak menyatakan pendapat (TMP/ disclaimer atau no opinion)}

Opini tidak menyatakan pendapat menyatakan bahwa laporan keuangan tidak dapat diyakini wajar atau tidaknya dalam semua hal yang material dikarenakan laporan keuangan tidak dapat diperiksa sesuai dengan standar pemeriksan. Ketidakyakinan tersebut disebabkan oleh pembatasan lingkup pemeriksaan dan hal tersebut harus diungkapkan dalam laporan hasil pemeriksaan yang memuat opini tersebut.

\section{Kerugian Daerah}

Dalam pemeriksaan BPK, selain melakukan pemeriksaan atas SPI, BPK juga melakukan pemeriksaan atas kepatuhan terhadap peraturan perundang-undangan (compliance audit). Arens, Elder dan Beasley (2012) menjelaskan bahwa audit kepatuhan dilakukan untuk menentukan apakah auditee mengikuti prosedur khusus, tata cata, serta peraturan yang ditetapkan oleh beberapa otoritas yang lebih tinggi. Pelaporan tentang kepatuhan terhadap perundang-undangan juga telah dijelaskan dalam Standar Pemeriksaan Keuangan Negara (SPKN). SPKN menyatakan bahwa dalam melaporkan 
kecurangan dan penyimpangan dari ketentuan perundang-undangan atau ketidakpatuhan, pemeriksa menempatkan temuan secara lugas dalam perspektif yang wajar.

Kerugian keuangan daerah dapat disebabkan oleh ketidakpatuhan terhadap perundang-undangan. Kerugian daerah adalah kerugian keuangan pemerintah daerah sebagai bagian kerugian keuangan negara yang dapat disebabkan oleh karena perbuatan/ tindakan pelanggaran hukum. UU nomor 1 tahun 2004 dan UU nomor 15 tahun 2006 menyatakan bahwa kerugian Negara/Daerah adalah kekurangan uang, surat berharga, dan barang, yang nyata dan pasti jumlahnya sebagai akibat perbuatan melawan hukum baik sengaja maupun lalai.

Menurut Peraturan Menteri Dalam Negeri Nomor 5 Tahun 1997 tentang Tuntutan Perbendaharaan dan Tuntutan Ganti Rugi Keuangan dan Barang Daerah disebutkan bahwa kerugian daerah adalah berkurangnya kekayaan daerah yang disebabkan oleh suatu tindakan melanggar hukum atau kelalaian bendaharawan atau pegawai bukan bendaharawan dan/atau disebabkan sesuatu keadaan di luar dugaan dan di luar kemampuan manusia (force majeure).

\section{Kesejahteraan Masyarakat}

Masyarakat madani mencerminkan suatu masyarakat yang sejahtera dan berkeadilan. Beberapa parameter masyarakat madani adalah tingkat pembangunan manusia, tingkat pengetahuan masyarakat, tingkat angka harapan hidup, dan tingkat kesejahteraan. Masyarakat madani memiliki perspektif yang lebih baik dalam melihat pemerintahannya sehingga dapat menciptakan fungsi pengawasan dan tata kelola pemerintahan yang lebih baik, baik perspektif dalam segi ekonomi, sosial maupun budaya (Despotis 2005).

Salah satu parameter dalam mengukur kesejahteraan masyarakat yang terwujud dalam masyaraat madani dapat dilihat dari IPM setiap daerah. United Nations Development Programme (UNDP) dalam Anand dan Sen (2000) mengatakan bahwa manusia merupakan makhluk primer dan sarana utama dalam pembangunan. Ada 12 kategori dalam pembangunan manusia (Ranis et al. 2006), yaitu: IPM itu sendiri, kesejahteraan mental, pemberdayaan, kebebasan berpolitik, hubungan sosial, kesejahteraan masyarakat, ketimpangan, kondisi kerja, kondisi rekreasi, politik dan keamanan, keamanan ekonomi, kondisi lingkungan. Negara-negara yang memiliki IPM yang baik cenderung memiliki tata kelola pemerintahan yang baik pula. Semakin baik pertumbuhan IPM maka semakin baik pula kualitas kehidupan masyarakat sehingga semakin baik pula pemerintahan yang dihasilkan (Ramachandran 2002).

Tingkat kesejahteraan masyarakat juga dapat diukur dengan melihat sejauh mana tingkat pendapatan yang diperoleh suatu daerah. Giroux dan McLelland (2003) membuktikan bahwa tingkat pendapatan masyarakat berpengaruh terhadap kualitas audit dan tingkat pengelolaan keuangan pemerintah daerah. Indikator yang digunakan adalah PDRB per kapita dan tingkat kesenjangan pendapatan. Dari PDRB per kapita dan tingkat kesenjangan pendapatan, pemegang kepentingan dapat melihat seberapa jauh pembangunan telah berhasil menyejahterakan masyarakatnya, dengan kata lain pemerataan pendapatan.

\section{Kerugian daerah berpengaruh terhadap opini pemeriksaan Atas LKPD}

BPK memberikan opini atas Laporan Keuangan Pemerintah Daerah (LKPD) berdasarkan hasil pemeriksaan yang memuat temuan, kesimpulan, dan rekomendasi. Setiap temuan dapat terdiri atas satu atau lebih permasalahan, yaitu berupa kelemahan sistem pengendalian intern (SPI) dan/ atau ketidakpatuhan terhadap ketentuan peraturan perundangundangan. Ketidakpatuhan ini dapat mengakibatkan kerugian negara/daerah, potensi kerugian negara/daerah, kekurangan penerimaan, penyimpangan administrasi, ketidakhematan, ketidakefsienan, atau ketidakefektifan (Badan Pemeriksa Keuangan 2015). 
Berdasarkan penjelasan tersebut, hipotesis yang dikembangkan adalah.

H1: Jumlah temuan kerugian daerah berpengaruh negatif terhadap opini pemeriksaan atas LKPD

H2: Nilai temuan kerugian daerah berpengaruh negatif terhadap opini pemeriksaan atas LKPD

\section{Tingkat kesejahteraan masyarakat berpengaruh terhadap opini pemeriksaan Atas LKPD}

Tingkat pembangunan masyarakat menunjukkan tingkat kemajuan yang dicapai suatu masyarakat. Tingkat pembangunan masyarakat dapat diukur salah satunya melalui IPM. Tata kelola pemerintahan yang baik mensyaratkan adanya keberadaan masyarakat yang tingkat pembangunannya baik pula (Ramachandran 2002). Berdasarkan penjelasan di atas dapat dikatakan bahwa tingkat kesejahteraan masyarakat akan meningkatkan tata kelola pemerintahan yang baik sehingga akan menghasilan akuntabilitas laporan keuangan yang lebih baik. Hipotesis yang dikembangkan adalah.

H3: Indeks pembangunan manusia berpengaruh positif terhadap opini pemeriksaan atas LKPD

\section{Tingkat kesejahteraan masyarakat dapat dilihat dari tingkat pendapatan yang diperoleh suatu daerah dan tingkat kesenjangan pendapatan pada masyarakat.}

Giroux dan McLelland (2003) membuktikan bahwa tingkat pendapatan masyarakat berpengaruh terhadap kualitas audit dan tingkat pengelolaan keuangan pemerintah daerah. Semakin sejahtera masyarakat maka masyarakat tersebut tidak lagi berkutat terhadap pemenuhan kebutuhan primer dan sekundernya sehingga mereka lebih memiliki fokus perhatian kepada pemerintahannya dan lebih lantang dalam menyuarakan pendapat sekaligus memberikan aspirasi. Berdasarkan penjelasan tersebut, hipotesis yang dikembangkan adalah.

H4: Produk domestik regional bruto berpengaruh positif terhadap opini pemeriksaan atas LKPD

H5: Tingkat Kesenjangan Pendapatan berpengaruh negatif terhadap opini pemeriksaan atas LKPD

\section{METODE PENELITIAN}

\section{Desain Penelitian}

Desain penelitian meliputi serangkaian pilihan pengambilan keputusan rasional, sehingga data yang diperlukan peneliti dapat dikumpulkan serta dianalisis untuk mencapai solusi (Sekaran 2007). Penelitian ini merupakan penelitian pengujian hipotesis yang memiliki tujuan untuk menguji pengaruh kerugian daerah dan kesejahteraan masyarakat terhadap opini pemeriksaan atas LKPD di Indonesia. Jenis penelitian ini adalah kausalitas yang bermaksud untuk mengungkapkan apakah kerugian daerah dan kesejahteraan masyarakat akan mempengaruhi opini pemeriksaan atas LKPD. Data penelitian ini diperoleh pada tahun 2013 dan 2014 sehingga penelitian ini merupakan penelitian cross section.

Faktor yang mempengaruhi opini pemeriksaan dalam penelitian ini dilihat dari dua faktor utama. Pertama, faktor kerugian daerah yang diambil dari dua parameter yaitu a) jumlah temuan kerugian daerah dan b) nilai temuan kerugian daerah. Kedua, kesejahteraan masyarakat selaku principal yang dilihat dengan tiga parameter yaitu, a) Indeks Pembangunan Manusia, b) Produk Domestik Regional Bruto per Kapita, dan c) Tingkat Kesenjangan Pendapatan.

\section{Operasionalisasi Variabel}

Variabel merupakan hal yang dapat membawa variasi pada suatu nilai. Nilai dapat berbeda dalam berbagai waktu untuk suatu objek atau orang yang sama, atau pada waktu yang sama untuk objek atau orang yang berbeda (Sekaran 2007). Penelitian ini merupakan studi empiris yang bertujuan untuk memperoleh bukti tentang pengaruh kerugian daerah (jumlah dan nilai temuan kerugian daerah) dan kesejahteraan masyarakat (IPM, PDRB per Kapita, dan Tingkat Kesenjangan Pendapatan) terhadap opini pemeriksaan 
atas LKPD

Variabel dependen dalam penelitian ini adalah opini pemeriksaan atas LKPD kabupaten/kota di Indonesia yang diproksikan dengan opini yang diperoleh dari BPK RI atas LKPD pemerintah kabupaten/kota tahun anggaran 2014 (OPINI). Pengukuran opini pemeriksaan menggunakan dummy, kode "4" untuk pemerintah daerah dengan opini WTP, kode "3" untuk pemerintah daerah dengan opini WDP, kode "2" untuk pemerintah daerah dengan opini TW, dan kode "1" untuk pemerintah daerah dengan opini TMP. Penelitian ini menguji lima variabel independen yang terbagi dalam dua aspek.

\section{Kerugian Daerah}

Terdapat dua variabel independen yang digunakan dalam penelitian ini yaitu jumlah temuan kerugian daerah (JUMLAH) dan nilai temuan kerugian daerah (LG10_NILAI).

\section{Jumlah Temuan Kerugian Daerah (JUMLAH)}

Jumlah temuan kerugian daerah diukur dengan cara menghitung jumlah total temuan kerugian daerah yang ditemukan oleh auditor BPK atas LHP kepatuhan terhadap peraturan perundang-undangan di pemerintah kabupaten/kota seluruh Indonesia.

\section{Nilai Temuan Kerugian Daerah (LG10_NILAI)}

Nilai temuan kerugian daerah diukur dengan cara menghitung jumlah total nilai kerugian daerah yang ditemukan oleh auditor BPK atas LHP kepatuhan terhadap peraturan perundang-undangan di pemerintah kabupaten/kota seluruh Indonesia. Besarnya nilai temuan kerugian daerah pemerintah daerah berbeda bahkan mempunyai selisih yang besar, sehingga dapat menyebabkan nilai yang ekstrem. Untuk menghindari adanya data yang tidak normal tersebut maka data nilai kerugian daerah perlu di-Lg10-kan.

\section{Kesejahteraan Masyarakat}

Terdapat tiga variabel independen yang digunakan dalam penelitian ini yaitu Indeks Pembangunan manusia (IPM), Produk Domestik Regional Bruto per Kapita (PDRBK), dan Tingkat Kesenjangan Pendapatan (Gini).

\section{Indeks Pembangunan manusia (IPM)}

Indeks Pembangunan Manusia merupakan ukuran yang dapat digunakan untuk melihat upaya dan kinerja pembangunan suatu wilayah. IPM adalah indeks komposit dari gabungan tiga indikator yaitu angka harapan hidup, angka melek huruf, dan standar hidup layak. Pengukuran IPM pemerintah daerah ini menggunakan skor data sekunder yang berasal dari website BPS.

\section{Produk Domestik Regional Bruto per Kapita (LG10_PDRBK)}

Besarnya PDRB per Kapita masing-masing daerah berbeda bahkan mempunyai selisih yang besar, sehingga dapat menyebabkan nilai yang ekstrem. Untuk menghindari adanya data yang tidak normal tersebut maka data PDRB per Kapita perlu di-Lg10kan. Variabel PDRB per Kapita diukur dengan logaritma natural PDRB per Kapita masing-masing daerah. Data dalam variabel ini diperoleh dari BPS tahun 2013 dan 2014.

\section{Tingkat Kesenjangan Pendapatan (GINI)}

Pengukuran tingkat kesenjangan pendapatan pemerintah daerah ini menggunakan data sekunder Gini Ratio yang berasal dari website BPS.

\section{Populasi dan Sampel}

Populasi dalam penelitian ini adalah seluruh pemerintah kabupaten/kota di Indonesia tahun 2013 dan 2014. Teknik pengambilan sampel yang digunakan di penelitian ini menggunakan teknik purposive sampling, yaitu pengambilan sampel dengan menggunakan kriteria yang ditentukan berdasarkan kebijakan dari peneliti. Kriteria penelitian sampel pada penelitian ini dirumuskan sebagai berikut.

Pemerintah kabupaten dan kota di 
Indonesia sampai dengan tahun anggaran 2013 dan 2014. Pemerintah kabupaten dan kota di Indonesia yang menyerahkan LKPD TA 2013 dan 2014 dan telah diperiksa oleh BPK RI pada TA 2014 dan 2015 serta tercantum dalam IHPS I dan II Tahun 2014 dan IHPS I 2015 BPK RI. Pemerintah kabupaten dan kota di Indonesia yang menyajikan informasi dan data yang dibutuhkan untuk pengukuran variabel penelitian seperti IPM, PDRB per Kapita, dan Tingkat Kesenjangan Pendapatan.

Jumlah akhir sampel penelitian disajikan dalam tabel berikut.

Tabel 1.

Jumlah Akhir Sampel Penelitian

\begin{tabular}{|c|c|}
\hline Kriteria Sampel & Jumlah \\
\hline 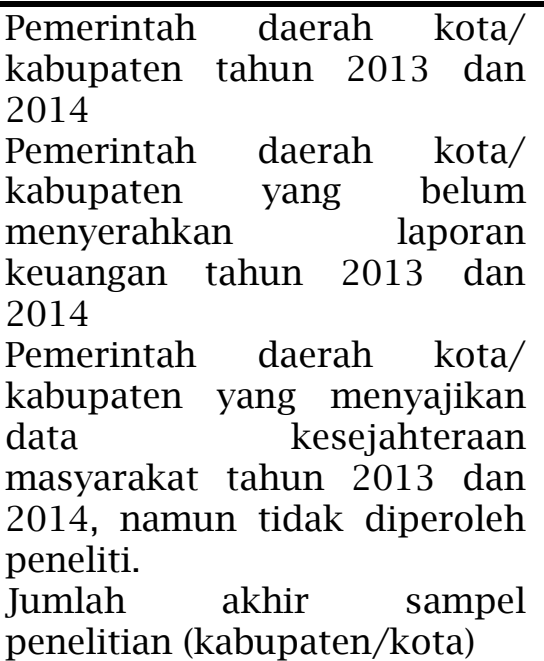 & (824) \\
\hline
\end{tabular}

Jenis dan Sumber Data

Sumber data dalam penelitian ini merupakan data sekunder (secondary data). Data sekunder merupakan data yang telah tersedia sehingga peneliti tidak perlu

Tabel 2.

Data dan Sumber Data

\begin{tabular}{|c|c|c|}
\hline No & Data & $\begin{array}{c}\text { Sumber } \\
\text { Data }\end{array}$ \\
\hline 1. & $\begin{array}{l}\text { Data opini yang } \\
\text { diperoleh } \\
\text { Pemerintah Daerah } \\
\text { dan Data temuan } \\
\text { kerugian daerah }\end{array}$ & $\begin{array}{l}\text { IHPS I Tahun } \\
2015 \text { dan } \\
\text { IHPS I dan II } \\
\text { Tahun } 2014 \\
\text { BPK RI }\end{array}$ \\
\hline 2. & $\begin{array}{l}\text { Data IPM, PDRB per } \\
\text { Kapita, dan Gini } \\
\text { Ratio }\end{array}$ & $\begin{array}{l}\text { BPS dan } \\
\text { Sumber } \\
\text { Lainnya }\end{array}$ \\
\hline
\end{tabular}

mengumpulkan sendiri (Sekaran, 2007). Data sekunder diperoleh dari pihak lain dan tidak langsung diperoleh oleh peneliti dari subjek penelitiannya.

\section{Metode Analisis Data}

Penelitian ini dirancang untuk memperoleh bukti empiris mengenai faktor-faktor yang berpengaruh terhadap jumlah temuan SPI dan kepatuhan. Data yang dikumpulkan diolah menggunakan software Statistical Package for Social Science (SPSS) versi 20.0 untuk mempermudah analisa data dan uji hipotesis. Penelitian ini menggunakan analisis regresi berganda yang terlebih dahulu dilakukan pengujian asumsi klasik yang terdiri dari uji normalitas, uji autokorelasi, uji heteroskedastisitas, dan uji multikolinearitas. Hal ini dilakukan untuk memastikan validitas hasil penelitian.

Model yang digunakan untuk menguji hipotesis dalam penelitian ini adalah model regresi berganda. Model regresi berganda digunakan untuk mengetahui pengaruh antara variabel independen dengan variabel dependen (Ghozali 2013). Persamaan model regresi berganda dalam penelitian ini dapat dirumuskan sebagai berikut:

$$
\begin{aligned}
\text { OPINI }=\beta_{0}+\beta_{1} \text { JUMLAH }+\beta_{2} \text { LG10_NILAI } \\
+\beta_{3} \text { IPM }+\beta_{4} \text { LG10_PDRBK }+\beta_{5} \text { GINI }+\varepsilon
\end{aligned}
$$

Keterangan:

$\begin{array}{ll}\text { OPINI } & \text { Opini Pemeriksaan atas LKPD } \\ \text { JUMLAH } & \begin{array}{l}\text { Jumlah Temuan Kerugian } \\ \text { Daerah }\end{array} \\ \text { LG10_NILAI } & \text { Nilai Temuan Kerugian Daerah } \\ \text { IPM } & \text { Indeks Pembangunan Manusia }\end{array}$

LG10_PDRBK Produk Domestik Regional Bruto per Kapita

$\begin{array}{ll}\text { GINI } & \begin{array}{l}\text { Tingkat Kesenjangan } \\ \text { Pendapatan }\end{array} \\ \beta_{0}, \beta_{1}, \ldots, \beta_{5} & \text { Koefisien Regresi } \\ \mathrm{e} & \text { errors }\end{array}$

\section{ANALISIS DAN PEMBAHASAN}

Statistik Deskriptif dan Uji Asumsi Klasik

Statistik deskriptif memberikan gambaran umum mengenai karakteristik variabel 
penelitian meliputi nilai terendah (minimum), nilai tertinggi (maximum), nilai rata-rata (mean) yang menggambarkan penyebaran data. Hasil statistik deskriptif disajikan dalam tabel berikut.

Berdasarkan Tabel 3 dapat diketahui jumlah observasi dalam penelitian $(\mathrm{N})$ adalah 158 pemerintah kabupaten/kota. Variabel dependen opini pemerintah daerah (OPINI) menghasilkan nilai rata-rata sebesar 3,3481. Hal tersebut menunjukkan bahwa sebagian besar opini yang diperoleh pemerintah kabupaten/kota adalah wajar dengan pengecualian.

Tabel 3.

Hasil Statistik Deskriptif

\begin{tabular}{lcccc}
\hline Variabel & N & Min & Max & Mean \\
\hline OPINI & 158 & 1.00 & 4.00 & 3.3481 \\
$\begin{array}{l}\text { JUMLA } \\
\text { H }\end{array}$ & 158 & 1.00 & 22.00 & 4.7532 \\
$\begin{array}{l}\text { LG10_ } \\
\text { NILAI }\end{array}$ & 158 & 1.29 & 4.38 & 2.9271 \\
$\begin{array}{l}\text { IPM } \\
\text { LG10_P }\end{array}$ & 158 & 49.40 & 80.14 & 70.0582 \\
$\begin{array}{l}\text { DRBK } \\
\text { GINI }\end{array}$ & 158 & 3.97 & 5.60 & 4.4504 \\
$\begin{array}{l}\text { Valid N } \\
\text { (listwise) }\end{array}$ & 158 & 0.21 & 0.48 & 0.3282 \\
\hline
\end{tabular}

Variabel jumlah temuan kerugian daerah (JUMLAH) mempunyai nilai rata-rata sebesar 4,7532 dengan jumlah temuan kerugian daerah tertinggi sebanyak 22 temuan yang diperoleh pemerintah kota Bandung (tahun 2014). Untuk nilai temuan kerugian daerah (LG10_NILAI) mempunyai nilai rata-rata sebesar 2,9271 dengan nilai temuan kerugian daerah tertinggi sebesar 4,38 atau Rp24.160.120.000,00 yang diperoleh pemerintah Kabupaten Mojokerto tahun 2013 dan jumlah temuan kerugian daerah terendah sebesar 1,29 atau Rp19.510.000,00 oleh pemerintah Kabupaten Kulon Progo tahun 2013.

Indeks pembangunan manusia (IPM) dengan nilai rata-rata 70,0582 menunjukkan cukup banyaknya pemerintah kabupaten/kota dalam kategori sedang. Nilai tertinggi sebesar 80,14 diperoleh pemerintah Kota Depok tahun
2013 dan nilai terendah sebesar 49,40 diperoleh pemerintah Kabupaten Tambrauw tahun 2014. Produk domestik regional bruto per Kapita (LG10_PDRBK) dengan nilai rata-rata 4,4504 dengan PDRB per Kapita tertinggi sebesar 5,60 atau Rp398.052.000,00 yang diperoleh pemerintah Kabupaten Teluk Bintuni tahun 2013 dan PDRB per Kapita terendah sebesar 3,97 atau Rp9.349.000,00 oleh pemerintah Kabupaten Tambrauw tahun 2013. Tingkat kesenjangan pendapatan (GINI) dengan nilai rata-rata 0,3282 dengan nilai tertinggi sebesar 0,48 diperoleh pemerintah kota Bandung (tahun 2014) dan nilai terendah sebesar 0,21 diperoleh pemerintah Kabupaten Tambrauw tahun 2013.

Penelitian ini telah memenuhi uji asumsi klasik yang terdiri dari uji normalitas data, uji multikolinieritas, uji autokorelasi, dan uji heteroskedastisitas. Oleh karena itu pengujian hipotesis dengan menggunakan analisis regresi berganda dapat dilakukan.

\section{Pengujian Hipotesis}

Pengujian regresi berganda terdiri dari uji signifikansi- $F$, uji signifikansi-- $t$ dan uji koefisien determinasi. Hasil pengujian regresi berganda tampak dalam tabel 4 .

Tabel 4.

Hasil Uji Regresi Berganda

\begin{tabular}{lcccc}
\hline \multicolumn{1}{c}{ Model } & $\begin{array}{c}\text { Expt } \\
\text { Sign }\end{array}$ & \multicolumn{1}{c}{ B } & $\begin{array}{c}t- \\
\text { value }\end{array}$ & \multicolumn{1}{c}{ Sig. } \\
\hline (Constant) & & 4.311 & 4.260 & .000 \\
Jumlah & + & .007 & .333 & .740 \\
LG10_Nilai & - & -.454 & -3.903 & .000 \\
IPM & + & .003 & .290 & .772 \\
LG10__PDRB & + & .098 & .497 & .620 \\
Gini & - & -.987 & -.718 & .474 \\
R & & .368 & & \\
R ${ }^{2}$ & & .136 & & \\
Adjust R & & .107 & & \\
F-value & & & 4.775 & \\
Sig & & & & .000 \\
\hline
\end{tabular}




\section{Uji Statistik F}

Uji F dilakukan untuk mengetahui apakah semua variabel independen secara bersama -sama berpengaruh terhadap variabel dependen. Berdasarkan hasil uji regresi pada tabel 4.7 terlihat bahwa signifikansi $\mathrm{F}$ sebesar 0,000 (0\%) lebih kecil dari 5\% sehingga dapat disimpulkan bahwa variabel jumlah temuan, nilai temuan, IPM, PDRB per Kapita, dan tingkat kesenjangan pendapatan berpengaruh terhadap opini pemerintah daerah.

\section{Uji statistik t}

Uji statistik $t$ digunakan untuk mengetahui pengaruh variabel independen secara individu terhadap variabel dependen. Dengan menggunakan batas signifikansi 0,05 (5\%), apabila nilai signifikansi variabel independen lebih kecil dari 5\% maka variabel tersebut berpengaruh terhadap variabel dependen.

Tabel 8 menunjukkan bahwa nilai signifikansi variabel independen yang di bawah 5\% hanya variabel LG10_NILAI yang berarti bahwa hanya variabel nilai temuan kerugian daerah yang secara individu berpengaruh terhadap variabel dependen (OPINI). Variabel JUMLAH, IPM, LG10_PDRBK, dan GINI mempunyai nilai signifikasi di atas 5\% yang berarti variabel jumlah temuan kerugian, indeks pembangunan manusia, PDRB per Kapita, dan tingkat kesenjangan pendapatan secara individu tidak berpengaruh terhadap variabel dependen.

Dari hasil pengaruh uji parsial (uji signifikansi-t), terlihat bahwa nilai probabilitas untuk variabel jumlah temuan kerugian (JUMLAH) sebesar 0,740 atau lebih besar dari 0,05 yang berarti tidak berpengaruh signifikan terhadap opini pemeriksaan atas LKPD, sehingga hipotesis pertama pada penelitian ini ditolak. Hal ini dapat dikarenakan bahwa dasar pertimbangan opini salah satunya adalah materialitas. BPK memberikan opini atas LKPD berdasarkan hasil pemeriksaan yang memuat temuan, kesimpulan, dan rekomendasi. Temuan yang sifatnya tidak material tidak akan mempengaruhi opini. Hal ini sesuai dengan panduan pemeriksaan LKPD BPK RI yang menyatakan bahwa pada dasarnya terdapat dua kondisi yang menentukan opini yaitu pembatasan lingkup pemeriksaan atau kecukupan bukti dan penyimpangan dari prinsip akuntansi atau salah saji. Kedua hal tersebut harus dikaitkan dengan tingkat materialitas dan dampaknya terhadap LK secara keseluruhan (pervasiveness).

Hasil pengujian menunjukkan bahwa nilai probabilitas untuk variabel nilai temuan kerugian (LG10_NILAI) sebesar 0,000 yang berarti berpengaruh signifikan terhadap opini pemeriksaan atas LKPD pada tingkat signifikansi 5\% dengan tanda koefisien negatif, sehingga hipotesis kedua pada penelitian ini diterima. Pemberian opini atas laporan keuangan harus didasarkan pada keyakinan yang memadai bahwa laporan keuangan telah disajikan secara wajar dalam semua hal yang material sesuai dengan prinsip akuntansi yang berlaku umum. Penyajian laporan keuangan secara wajar artinya bahwa tidak terdapat salah saji yang material dalam pelaporan keuangan.

Hasil pengujian menunjukkan bahwa nilai probabilitas untuk variabel indeks pembangunan manusia (IPM) sebesar 0,772 yang berarti tidak berpengaruh signifikan terhadap opini pemeriksaan atas LKPD pada tingkat signifikansi $5 \%$ dengan tanda koefisien positif, sehingga hipotesis ketiga pada penelitian ini ditolak. Hasil penelitian ini tidak sesuai dengan penelitian yang telah dilakukan sebelumnya oleh Ramachandran (2002) yang menyatakan bahwa tata kelola pemerintahan yang baik mensyaratkan adanya keberadaan masyarakat yang tingkat pembangunannya baik pula. Hal ini mungkin dikarenakan pada kenyataannya bahwa opini diberikan kepada pemerintah daerah tanpa perlu melihat apakah masyarakat di daerah tersebut memiliki tingkat pembangunan masyarakat yang tinggi atau rendah. Hal ini senada dengan SPKN bahwa pemeriksaan atas LKPD merupakan jenis pemeriksaan keuangan yang dilakukan oleh BPK dengan tujuan memberikan pernyataan opini tentang tingkat kewajaran informasi yang disajikan dalam LKPD.

Hasil pengujian terhadap variabel 
yang mewakili tingkat pendapatan masyarakat menunjukkan bahwa nilai probabilitas untuk variabel PDRB per kapita (LG10_PDRBK) sebesar 0,620 yang berarti tidak berpengaruh signifikan terhadap opini pemeriksaan atas LKPD pada tingkat signifikansi 5\% dengan tanda koefisien positif, sehingga hipotesis keempat pada penelitian ini ditolak. Hasil pengujian untuk variabel tingkat kesenjangan pendapatan (GINI) sebesar 0,474 yang berarti tidak berpengaruh signifikan terhadap opini pemeriksaan atas LKPD pada tingkat signifikansi 5\% dengan tanda koefisien negatif, sehingga hipotesis kelima pada penelitian ini ditolak. Hasil penelitian ini tidak sesuai dengan penelitian yang telah dilakukan sebelumnya oleh Giroux dan McLelland (2003) membuktikan bahwa tingkat pendapatan masyarakat berpengaruh terhadap kualitas audit dan tingkat pengelolaan keuangan pemerintah daerah. Hal ini mungkin dikarenakan pada kenyataannya bahwa tingkat pendapatan yang menjadi ruang lingkup pemeriksaan hanya sebatas pada pendapatan yang disajikan pada LKPD dan tidak memperhitungkan tingkat pendapatan masyarakat apakah tinggi atau rendah. Sesuai dengan penjelasan Pasal 16 ayat (1) UU No. 15 Tahun 2004 tentang Pemeriksaan Pengelolaan dan Tanggung Jawab Keuangan Negara, opini merupakan pernyataan profesional pemeriksa mengenai kewajaran informasi keuangan yang disajikan dalam laporan keuangan yang didasarkan pada kriteria.

\section{Uji Koefisien Determinasi (Adjusted $\mathbf{R}^{\mathbf{2}}$ )}

Uji koefisien determinasi bertujuan untuk mengukur kemampuan model regresi dalam menerangkan variasi dependen. Berdasarkan tabel 4.7 terlihat bahwa nilai adjusted $\quad R$-square $\quad 0,107 \quad(10,7 \%)$. Berdasarkan pengujian tersebut dapat disimpulkan bahwa model penelitian mampu menjelaskan variasi variabel dependen sebesar 10,7\% sedangkan sisanya sebesar 89,3\% dijelaskan oleh variabelvariabel lain di luar model penelitian. Hal ini berarti masih banyak variabel di luar model penelitian yang berpengaruh terhadap opini pemerintah daerah.

\section{SIMPULAN}

Penelitian ini merupakan studi empiris yang bertujuan untuk memperoleh bukti tentang pengaruh kerugian daerah (jumlah dan nilai temuan kerugian daerah) dan kesejahteraan masyarakat (IPM, PDRB per kapita, dan Tingkat Kesenjangan Pendapatan) terhadap opini pemeriksaan atas LKPD. Berdasarkan hasil penelitian dan pengolahan data yang telah dilakukan, dapat diambil kesimpulan bahwa terdapat pengaruh yang signifikan secara simultan (bersama-sama) antara jumlah temuan kerugian daerah, nilai temuan kerugian daerah IPM, PDRB per kapita, dan tingkat kesenjangan pendapatan terhadap opini pemeriksaan atas LKPD. Serta nilai kerugian daerah yang berpengaruh secara individual terhadap opini pemeriksaan atas LKPD. Variabel independen lainnya (jumlah temuan kerugian daerah, IPM, PDRB per kapita, dan tingkat kesenjangan pendapatan) secara individual tidak berpengaruh terhadap opini pemeriksaan atas LKPD.

\section{KETERBATASAN DAN SARAN}

\section{Keterbatasan}

Penelitian ini memiliki keterbatasan data terkait tingkat kesenjangan pendapatan yang hanya menggunakan hasil publikasi yang berasal dari website masing-masing BPS Kabupaten/Kota. BPS Pusat tidak dapat menyediakan data untuk keseluruhan Kabupaten/Kota di Indonesia. Keterbatasan data penelitian mungkin menjadi salah satu penyebab besarnya tingkat signifikasi hasil uji regresi (pengaruh uji parsial atau uji signifikansi-t) kesejahteraan masyarakat dalam menjelaskan variasi opini pemeriksaan atas LKPD.

\section{Saran}

Dari kesimpulan dan keterbatasan penelitian yang ada, penulis memberikan beberapa saran terkait penelitian ini, yaitu Berdasarkan tabel 4.7, penelitian ini hanya menjelaskan 10,7\% pengaruh antara variabel kerugian daerah (jumlah dan nilai temuan kerugian daerah) dan 
kesejahteraan masyarakat (IPM, PDRB per kapita, dan Tingkat Kesenjangan Pendapatan) terhadap opini pemeriksaan atas LKPD. Oleh karena itu, masih terdapat $89,3 \%$ variabel lain yang dapat berpengaruh terhadap opini pemeriksaan atas LKPD. Dengan demikian, diharapkan penelitian selanjutnya dapat menambahkan variabel independen lainnya yang diduga mempunyai pengaruh terhadap opini pemeriksaan atas LKPD, misalnya temuan terkait penyajian LKPD, sistem pengendalian internal pemerintah daerah, dan indikator lainnya sehingga dapat memberikan data penelitian yang lebih komprehensif atas faktor-faktor yang mempengaruhi opini pemeriksaan atas LKPD. Selain itu, Menambah jumlah sampel penelitian sehingga dapat mewakili persepsi terhadap opini pemeriksaan atas LKPD.

\section{DAFTAR PUSTAKA}

Abdullah, S. dan J. A. Asmara. 2006. Perilaku Oportunistik Legislatif dalam Penganggaran Daerah. Simposium Nasional Akuntansi IX, Padang.

Adzani, A. H. dan D. Martani. 2014. Pengaruh Kesejahteraan Masyarakat, Faktor Politik dan Ketidakpatuhan Regulasi Terhadap Opini Audit Laporan Keuangan Pemerintah Daerah. Simposium Nasional Akuntansi XVII, Mataram.

Anand, S. dan A. Sen. 2000. The Income Component of the Human Development Index. Journal of Human Development, 1.(1): 83 - 106.

Arens, A. A., R. J. Elder dan M. S. Beasley. 2012. Auditing and Assurance Services: An Integrated Approach. 14th ed. New Jersey: Pearson Education, Inc.

Badan Pemeriksa Keuangan. 2007. Peraturan Badan Pemeriksa Keuangan No. 1 Tahun 2007 tentang Standar Pemeriksaan Keuangan Negara. Jakarta: Badan Pemeriksa Keuangan RI.

2014. Ikhtisar Hasil Pemeriksaan Semester I Tahun 2014. Jakarta: Badan Pemeriksa Keuangan RI.

2015. Ikhtisar Hasil Pemeriksaan Semester II Tahun 2014. Jakarta: Badan Pemeriksa Keuangan RI.
. 2015. Ikhtisar Hasil Pemeriksaan Semester I Tahun 2015. Jakarta: Badan Pemeriksa Keuangan RI.

2015. Mendapat Opini WTP, Kesejahteraan Rakyat Harus Meningkat. Diakses pada tanggal 17 Februari 2016 pukul 20.00 WIB dari http://www.bpk.go.id/.

Badan Pusat Statistik. 2014. Gini Ratio Menurut Provinsi Tahun 1996, 1999, 2002, 2005, 2007-2013. Diakses pada tanggal 27 April 2016 pukul 21.30 WIB dari http://www.bps.go.id/.

2014. Indeks Pembangunan Manusia Tahun 2014. Jakarta: Badan Pusat Statistik.

2014. Produk

Domestik Regional Bruto Kabupaten/ Kota di Indonesia 2010-2014. Jakarta: Badan Pusat Statistik.

Davis, J. H., F. D. Schoorman dan L. Doaldson. 1997. Toward a stewardship theory of management. Academy of Management Review, 22 : 20-47.

Ghozali, I. 2013. Aplikasi Analisis Multivariate dengan Program IBM SPSS 21 Update PLS Regresi. Edisi Ketujuh. Semarang: Badan Penerbit UNDIP.

Giroux, G. dan A. J. McLelland. 2003. Governance Structures and Accounting at large Municipalities. Journal of Accounting and Public Policy, 22: 203-230.

Despotis, D. K.. (2005). Measuring human development via data envelopment analysis the case of asia and the pacific. OMEGA, 33(5): 385-390.

Jensen, M. C. dan W. H. Meckling. 1976. The Theory of The Firm: Manajerial Behaviour, Agency Cost, and Ownership Structure. Journal of Financial and Economics, 3: 305-360.

Ramachandran, H. 2002. Governance and People's Participation: Vision 2020. In India Vision 2020: Report Plus Background Papers, Planning Commission, Government of India, New Delhi.

Ranis, G., F. Stewart dan E. Samman. 2006. Human Development: Beyond Human Development Index". Journal of Human Development, 7 (3): 324-358.

Republik Indonesia. 2006. Undang-Undang Nomor 15 Tahun 2006 tentang Badan Pemeriksa Keuangan Republik Indonesia. 2003. Undang-Undang No 17 Tahun 2003 tentang Keuangan 
Negara.

. 2004. Undang-Undang No. 15 Tahun 2004 tentang Pemeriksaan Pengelolaan dan Tanggung Jawab Keuangan Negara. Jakarta: Pemerintah Republik Indonesia.

.2004. Undang-Undang No. 1 Tahun 2004 tentang

Perbendaharaan Negara.
1997. Peraturan

Menteri Dalam Negeri No. 5 Tahun 1997 tentang Tuntutan Perbendaharaan dan Tuntutan Ganti Rugi Keuangan dan Barang Daerah.

Sekaran, U. 2007. Research Methode for Bussines: Metode Penelitian untuk Bisnis. Edisi Keempat. Jakarta: Salemba Empat. 
